\title{
CHRISTIAN IDENTITY AND THE ENVIRONMENT
}

\section{Tommy Magagula}

United Theological College, Harare Zimbabwe

dingz777@yahoo.com

\section{ABSTRACT}

A quick glance at the campus of many a theological college in Zimbabwe reveals the need to entrench environmental ethics which transcend personal and traditional convictions. This paper seeks to be a prophetic voice on this topic by exploring the essentials of Christian ethics and the way in which the entrenchment of such ethics may impede or enhance our stewardship of natural resources. We will explore the hopelessness of religious fatalism and the entrenched beliefs that prevent us from making optimal environmental decisions. The article specifically focuses on the impact of waste management in Zimbabwe. The errors of being short-sighted in our religiosity will be scrutinised, especially regarding the impact of our decisions on environmental management.

Key words: Christian ethics; Zimbabwean environmental management; religious fatalism; Christian identity; waste disposal

\section{INTRODUCTION}

Zimbabwe allegedly has 80 per cent of the population affirming Christianity as their religion of choice. Cynics place the estimate at 51 per cent. Nevertheless, if as ministers we could strive to reach five out of 10 people with a message of environmental responsibility, that would render fertile ground in influencing people's mind-set positively in terms of environmental consciousness. Once pastors and Christian leaders note how much power they wield, then our ethical conduct will be worthy of emulation. Instead of mourning and whimpering about darkness, teaching Christian ethics will be lighting the candle.

\section{UNISA}


Dahm (www.societasethica.info/annual.../programme-se-maribor-2014-final. pdf) mentions one of the five essentials of Christian ethics as responsibility against fatalism. MacMillan English dictionary (www.macmillandictionary.com/) defines fatalism as the 'belief that we cannot prevent bad things from happening to us'. This article contends that we have developed this fatalism whilst failing to be answerable for our environment.

\section{MOTIVATION}

The concern of environmental stewardship as explored in this article sprung from a 2013 Easter Bible study which took place in Nkulumane UCCSA church. The topic under discussion was stewardship of natural resources. The prodding of members about irresponsible waste management drew many comments.

During discussions on waste disposal, older women argued for the return to using washable nappies rather than disposable nappies. Their argument was that disposed nappies in dumpsites may find their way into our water sources, posing a health hazard. In rebuttal, the younger liberated women said there was no time to wash nappies as they work and have to raise children at the same time. When quizzed further on why they do not burn the disposable nappies, they replied that it was against the African culture to burn a baby's excrements. This sheds light on Mbiti's (www.afrikaworld.net/afrel/motivation.html) assertion that Africans are 'notoriously religious'.

At the close of the mentioned Easter celebrations, we endeavoured to formulate a suggested solution to this worrying behaviour in the chain of water and environmental management. It was agreed that everyone in that room would in future show responsibility in keeping our environment clean. The group committed to no littering of our roadsides with papers. One speaker asked us to check where we were seated, upon which we all noted how we had been littering without flinching. Indeed, it is easy to see a speck in someone's eye whilst failing to see the log in one's own eye. For me, Bible studies become topical when they force us to be introspective. The event promptly became our 'Open Sesame' to future responsible stewardship.

We have to accept that we cannot endanger our lives by following irresponsible waste management methods. It is also necessary to teach our children to imitate our responsibilities to nature. Sunday school children should be taught to ensure that they do not litter our earth.

In summation, we have a joint responsibility to make a difference as Christians. There are indications that the secular world is doing a better job than we are at environmental management. This requires self-introspection to probe the reasons why religious persons fall short in making the right decisions - looking specifically at religious fatalism and entrenched cultural convictions. As proclaimed Christians, we should always remind ourselves to be good stewards of this earth. 


\section{ENVIRONMENTAL STEWARDSHIP WITHIN A RELIGIOUS CONTEXT}

In the words of Boesak (https://books.google.co.zw/books?isbn=0802841139) from his book Black theology, he defines theology as 'a critical reflection on society and the life of the Church'. This paper will endeavour to tackle both.

After the mentioned Easter celebrations (and ensuing discussion on waste disposal) the author was tasked by a Senior Pastor to prepare a Bible study dealing with stewardship and our lack of responsibility towards the environment. When the congregants were prodded on the issue of disposable nappies, the church was figuratively set alight. By the time we separated, we were no longer the same people. The discussion prompted soul-searching introspection. Environmental stewardship was highlighted as an issue that triggers theological and ethical reflections; calling for nothing less than a radical paradigm shift. The main theme of the Bible study was Genesis 1:22: '... and God saw that it was good'.

When the group deliberated about tree planting, everyone was relatively comfortable and spoke freely about the number of trees they had planted. A discussion on water conservation was another area of agreement. Even the emphasis on keeping wetlands to protect our water tables received unanimous agreement. However, reference to the problem of disposable nappies took most of the congregants out of their comfort zone. Possible reasons for this discomfort need to be mentioned. Generally, Zimbabweans pride themselves for being hygienic. Disposable nappies are made of plastic and paper and take very long to reach a bio-degradable stage. They are imported from South Africa and other neighbouring countries. Thus far, Zimbabwean city councils seem unable or reluctant to address the problem of disposable nappies by means of bylaws or even awareness programmes that highlight the management of used nappies. Consequently, the younger generation of mothers and fathers just discard the disposable nappies after they have been soiled.

In the past parents used nappies made of cloth for their babies. When the nappies grew old and at times to a thread-bare stage, they would use it for other things like wiping the floor or dusting their tables. There was an unwritten rule that one was supposed to use it until it had gone through many lives. The nappy had nine lives like a cat. Moreover, cloth nappies are bio-degradable when buried in the ground. Sadly, the same thing cannot be said of disposable nappies, which are not only litter but also a visible health hazard.

A programme insert on Zimbabwe Broadcasting Television chronicled various dumpsites in Harare (which used to be called the Sunshine City). The eyesore of dumpsites was shown to be home to a multitude of green flies. A nurse (interview: anonymous, Harare Central Hospital,15/06/2015) explained how these dumpsites become a breeding ground for diseases. As reported on the Zimbabwean Broadcasting Television, most Zimbabweans know that the bulk of used disposable nappies find 
their way to these waste disposal areas, which are at times located in the central business district. Even more worrying is the fact that many used nappies are simply thrown into ridges or drainage systems in the hope that the rains will clean them up. Here the waste is often sniffed out by dogs, who then return to their domestic environment bearing communicable diseases.

The current situation of waste management in Zimbabwe (specifically Harare), and the blatant denial of the spiralling problem of disposable nappies, compel one to believe that there is no will or conviction to address the problem. One cannot help but point towards possible service delivery corruption causing havoc in the environmental management of our country. Poor service delivery can be traced back to companies that have won tenders to purify water and clean up the cities (www. zimbabwesituation.com). However, it is evident that these companies have failed in their mandate. A quick look at most surroundings will show that our environment has become an eyesore. Waste is being dumped when everyone has gone to sleep because the waste disposal companies try to avoid attracting a fine (jsd-africa. com/.../Waste\%20Management\%20in\%20Bulawayo\%20City\%). When (on one of those very rare occasions) the Harare City Council had done some cleaning, and we could celebrate that at least some diseases had been tackled, it was noted the very next day that there was an even larger consignment of used nappies dumped into the drainage ridges to be ferried away by water.

This dire situation explains why our water is no longer potable? Zimbabwe has many citizens who live in poor conditions; only the rich can resort to bottled water. Ironically, the plastic water bottles add to the problem, since they are often thrown out of windows with no concern of how we are polluting the earth. Sadly, a scandal was exposed by the media (www.zimbabwesituation.com > the latest articles) of some bottling companies who were selling contaminated water, as shown through random laboratory tests. Some newspapers (https://www.newsday.co.zw/ 2013/04/06/ bottled-water-scandal-exposed/) went on to sensationalise the results in headlines such as 'Harare's bottled urine'. Could it be (in view of 80 per cent Zimbabweans who claim to be Christians) that some of the people who behaved this scandalously are Christians? Somehow, it has become acceptable to gain wealth without letting one's ethos shape the decisions we take, which bears evidence just how unethical Christians have turned out to be. Harare's bottled water companies have been discovered to cut corners by bottling contaminated water (www.herald. co.zw/10-bottled-water-brands-a-health-risk/). Surely, is it not possible to find such employees who do such things in our churches? If so, our Christian identity is in great danger.

From the above discussion, it seems as if consumerism has also caught up with the Christian community. We only consume but do nothing about replenishing the resources for our progeny. On our theological campus, there was a lot of talk about disposable nappies, which really did not come up with a solution. There was 
just an uneasy silence in that community meeting. There was a brief respite but on subsequent days, disposed nappies were once again decorating the periphery bushes like confetti. It needs to be noted that the same concern was raised by Bulawayo residents, who also bemoaned the quick spread of cholera and other water borne diseases.

\section{ENVIRONMENTAL MANAGEMENT IN CONFLICT WITH TRADITIONAL AND RELIGIOUS CONVICTION}

In a book entitled God, creation and climate change: Spiritual and ethical perspectives (Bloomquist 2009), the question of theodicy comes into play. 'Some people view climate change as if God has disappeared from the scene, had been pushed to the margins by human activity and was no longer active in the cosmos' (Bloomquist 2009, 14). Even diseases are seen as punishment by some Christians, according to the introductory comments of this book. We conveniently blame God when we are responsible for unethical conduct that ends up back-firing on us. God is not responsible for the depletion of the ozone layer. We do not even flinch as we destroy forests in the name of development. Most rural communities still resort to the archaic method of bush fires to clear fields. This is causing environmental damage at a massive scale (https://www.newsday.co.zw/2014/07/30/veld-fires-costzimbabwe/).

Buchanan (2010) in The Christian Century..., a Christian magazine, has an interpretation penned by Cunningham. It proposes a re-think of the creation story with the title 'What Genesis doesn't say'. He propounds that following the fall, Adam did not forfeit his Imago Dei - 'i.e. his rational powers and, much more important, his body'. But Adam did lose his likeness [similitudo] with God; a similitude that signalled a 'spiritual similarity with God' (Buchanan 2010, 22). This article contends that our environmental sins are making us lose the spiritual aspect of this similitude with God.

Once more we explore the debate of that Easter meeting; the participants spoke about how they had engaged the council of the area to do something about meting out punishment or deterrent fines to offending mothers. Subsequently some young mothers raised the issue of the environment and human rights. The discussion took a turn when one liberated mother quizzed how mothers can be expected to change nappies and fathers are not? One of them asked if we were sure it is mothers and not fathers who negligently dispose of nappies. This illustrated entrenched cultural convictions which need to be overcome if we wish to address the problem of environmental management as a group and a society. One young mother asked where mothers should get the time to wash cloth nappies, go to work and go on to multi-task in other demanding household chores. When she challenged the males in that room, the only response was grumbling. Another woman opined that on that very morning, 
the Sunday school children and some women had gone around picking up litter from the surroundings. That litter could not have been caused by women only. Yet another female participant asked us to look at the floor. Only then did we realise that it was littered with bottle tops, tissue paper, empty cans and other litter. It was as if we assumed some magic wand that would sweep the dirt away. A lot of eyes stayed on the floor because they were ashamed at meeting that woman's eyes. In this manner, the very participants who were discussing environmental stewardship illustrated that they did not fully commit to resolving the problem, but rather contributed to the problem through non-compliance with our Biblical responsibility to take care of this planet.

On a positive note, it was revealed at that Easter gathering that different city councils in the country do not accept disposable nappies when placed in collected bins. Although it does at first seem like an attempt at controlling this waste disposal, one needs to ask what the alternative would be - is there a proper alternative structure in place to facilitate the logistics of this disposal, or will it merely lead to more nappies being dumped in the streets, waterways and fields. As a recommendation, the local church's Health Committee was asked to meet with the local councillor so that they could be told about acceptable ways of disposing nappies; which was a valid contribution on the issue of health care. Since we all came from different parts of Zimbabwe, we could all go back to pressurise our members of parliament and other leaders to address the problem.

The theologian, Lapsley (quoted in Childress and MacQuarrie 1986, 196), argues that Judeo-Christianity risks being superseded by 'Eastern philosophies and religions or to pantheism and animism'. Lapsley (quoted in Childress and MacQuarrie 1986) argues that these religions can provide alternative foundations other than the theology of dominion argued in the creation story of Genesis. He contends that this 'despotic view' is endemic to the traditional metaphysics of Judeo-Christian traditions. His solution is that we all remember to be trustees in protecting and developing the natural world in accordance with God's purpose (Lapsley quoted in Childress and MacQuarrie 1986, 196). He cites Philippians 2:5-11, stating that the dominion which is advocated for in this New Testament scripture is in line with Christ's model. In other words, if we love our neighbour as we love ourselves, we make use of Christ as the standard of our behaviour. In that way, we can boldly proclaim like the apostle Paul: 'Imitate me as I imitate Christ' (1 Corinthian 11:1). Lapsley's strongest line of argument (quoted in Childress and MacQuarrie 1986, 196) is his allusion to the pollution of water, air and land. Our behaviour as Christians certainly leaves a lot to be desired.

The author spent the greater part of 2002 in Kiribati Island, observing that global warming poses a looming danger of the sea swallowing up the island. It was observed that the sea water was filling a sizeable area of the house we lived in. Many scientists agree that most Pacific islands run a risk of being subsumed by sea 
water (news.nationalgeographic.com/150213-tuvalu-sopoaga-kench-kiribati). This source states that the President of the Maldives is already looking for land for his people. Recently on a visit to Maphisa (a rural place located in the southern part of Zimbabwe) the author noted that there is a lot of desertification and trees are falling to the axe. Furthermore, the youths who are church members are engaged in gold panning, which at times may lead to siltation of rivers. The use of mercury, which finds its way into the water of the rural population during the extraction of gold, is exacerbating the problem through these unacceptable methods of mining.

Personally, that Easter experience was unforgettable and it made me revisit the issue of dominion. Dominion of the world is certainly not synonymous with the desecration of the ecological system. This theological perspective has led to a steady decimation of the earth's resources. Makamure writes: 'However, the Bible in actuality does not affirm such an exploitative approach to the earth...[and] the way out of our ecological crisis is to undergo spiritual conversion....and respectful living with nature for this conversion' (Makamure quoted in Phiri and Werner 2013, 718).

\section{SOLUTIONS}

This article concludes that our blame of young mothers may have ignored the demands made on their well-being, time and attention. In retrospect, we need to rethink how we can be a voice that cannot be ignored by our leaders. As we correct unacceptable behaviour, we have to take cognisance that we do not target the already marginalised. In preaching, areas can be pointed out that require prioritisation, while acting as a conduit prophetic voice. The author feels compelled to take pictures highlighting these unsightly masses of rubbish and to produce newspaper articles that will hopefully spur readers on to be more environmentally conscious.

A possible solution is the buying of biodegradable disposable diapers. Those that are not biodegradable should be heavily taxed so that the money can be utilised in waste management by the country's city councils. Furthermore, the punitive taxation will assist in water purification by the government. In addition, non-bio degradable plastic papers could be collected by recycling companies that can receive tax exemptions from the government of Zimbabwe.

A programme screened on Canal France News channel (19/10/2011) showed how Rwanda spruced up its image in leaps and bounds. It banned the importation of plastic papers, save for very crucial items. That simply means plastics do not block the drainage system, do not affect the vegetation, and are not swallowed by livestock and other animals. Apparently, the initial response was an outcry but now the effects of the ban are bearing fruit. In Rwanda, it is no longer the genocide that defines their identity, but their fight to make Africa green again.

More solutions include positive and negative sanctions on offenders. Positive sanctions will include giving incentives to members who show environmental 
awareness. Heavy taxation could be made on offenders of environmental laws, including those who drive fuel guzzling cars (such as some flamboyant Zimbabwean Pastors who drive Hummers). Land degradation, river bank cultivation, air, land and river pollution are all good topics in teaching eco-theology to students.

Another possible panacea is to act as pressure group as Christians. This could be done through making disposable nappies more expensive so that it will accommodate more cleaning service provision.

We all made promises after that Bible study to revert to the old type of cloth nappies wherever feasible. They are eco-friendly and bio-degradable. This will show responsibility for the environment. We all vowed to be more environmentally friendly, even in the refusal to litter the countryside by throwing litter out of moving vehicles. We all immediately picked up the litter on the floor and dumped it into the bins. With responsibility comes the twin brother, accountability. We might no longer believe in the existence of hell, but at least we can ensure that our lifestyle does not make the lives of others living hell. Instead of simply blaming young mothers, we all swore we would find ways of pressurising our ward leaders on acceptable and legal ways of garbage disposal.

McDaniel (1995), in the book With roots and wings: Christianity in an age of ecology and dialogue, advocates for reverence of life: 'We have reverence for life when we feel kinship with their joys and sufferings, and when we want for them the kind of happiness we want for ourselves' (McDaniel 1995, 47). Reverence of flora and fauna will be the right step in a positive dominion. Anyone who has seen wildlife that has died in a fire realises the need to revere ecology. At the moment, it seems that the secular world is doing a better job in preserving the ecological balance.

Planting of trees should be encouraged. One might not immediately enjoy the fruits or shade of that tree but the coming generation will certainly enjoy those trees. The random cutting of trees to satisfy our consumerism will boomerang. Environmentally responsible actions will result in a futuristic and not myopic trajectory. What is done by Christians in Zimbabwe may reflect positively on the lives of people in Kiribati, in Malawi, in Namibia and the world at large. We should all vow to be good stewards so that God can still proclaim the world to be looking good. It is unacceptable to dispose of nappies irresponsibly.

\section{CONCLUSION}

In an article featured in the Sunday Times, 14 July 2013, Nelson Mandela was asked how he wanted to be remembered. He serenely replied that he did not want to be remembered as a prophet or messiah, but chose to be remembered as a servant of the people. The article points out how Mandela constantly reminded anyone who cared to listen, of the power of the collective. This article purports that as a collective, we can solve the issue of waste disposal. It is a touching fact that Mandela contributed a 
third of his presidential salary to children's causes (www.timeslive.org.za). This has made his shoes extremely difficult to fill by other presidents and Africans. In a speech delivered by this illustrious Nobel Peace Prize winner, he called for children to be scriptwriters of their destiny and lead the way for a brighter future for their country, continent and world (www.timeslive.org.za). This cannot be overemphasised. We are scriptwriters set to make a difference in what we do in becoming stewards of the earth's resources.

It is with faith and conviction that this article advocates making a difference in our countries of origin on the African continent. We can all be pencils in God's hands. If we are Imago Dei, let it show in our taking full responsibility for the ecological sustenance of nature in all its forms. Such responsibility will redefine us as Christians.

\section{REFERENCES}

Boesak, A. (https://books.google.co.zw/books?isbn=0802841139).

Bloomquist, K.L. ed. 2009. God, creation and climate change: Spiritual and ethical perspectives. Minneapolis: Lutheran University Press.

Buchanan, J.M. ed. 2010. The Christian century: Thinking critically, living faithfully.

Childress, J.F., J. MacQuarrie, ed. 1986. The Westminster dictionary of Christian ethics. Philadelphia: The Westminster Press.

Dahm (www.societasethica.info/annual.../programme-se-maribor-2014-final.pdf).

McDaniel, J.B. 1995. With roots and wings, Christianity in an age of ecology and dialogue. Maryknoll: Orbis Books.

MacMillan English dictionary (www.macmillandictionary.com).

Mbiti (www.afrikaworld.net/afrel/motivation.html).

Phiri, I.A., D. Werner, ed. 2013. Handbook of theological education in Africa. Dorpspruit: Cluster Publications.

www.christiancentury.org (accessed 16/10/2014)

www.herald.co.zw/10-bottled-water-brands-a-health-risk/

www.jsd-africa.com/.../Waste\%20Management\%20in\%20Bulawayo\%20City\%

www.news.nationalgeographic.com/.../150213-tuvalu-sopoaga-kench

www.kiribatiwww.newsday.co.zw/ 2013/04/06/ bottled-water-scandal-exposed/

www.newsday.co.zw/2014/07/30/veld-fires-cost-zimbabwe/

www.sundaytimes.org.za (accessed 11/11/2014)

www.timeslive.org.za (accessed 20/07/2015)

www.zimbabwesituation.com (accessed 11/11/2014) 